\title{
Capturing and Evaluating the Effects of the Expansive Species Ailanthus altissima on Agro-Ecosystems on the Ionian Islands ${ }^{\dagger}$
}

\author{
Yorghos Voutos ${ }^{1, *} \mathbb{C}$, Nicole Godsil ${ }^{2}$, Anna Sotiropoulou ${ }^{1}$, Phivos Mylonas ${ }^{1} \mathbb{D}$, Pavlos Bouchagier ${ }^{3}$, \\ Themis Exarchos ${ }^{1}$, Aristotelis Martinis ${ }^{2}$ and Katerina Kabassi ${ }^{2}$ (i)
}

1 Department of Informatics, Ionian University, 49100 Corfu, Greece; annasoti@ionio.gr (A.S.); fmylonas@ionio.gr (P.M.); exarchos@ionio.gr (T.E.)

2 Department of Environment, Ionian University, 29100 Zakynthos, Greece; n.godsil@ionio.gr (N.G.); amartinis@ionio.gr (A.M.); kkabassi@ionio.gr (K.K.)

3 Department of Food Science and Technology, Ionian University, 28100 Argostolion, Greece; pavlosbouchagier@yahoo.com

* Correspondence: c16vout@ionio.gr

+ Presented at the 13th EFITA International Conference, online, 25-26 May 2021

check for updates

Citation: Voutos, Y.; Godsil, N.; Sotiropoulou, A.; Mylonas, P.; Bouchagier, P.; Exarchos, T.; Martinis, A.; Kabassi, K. Capturing and Evaluating the Effects of the Expansive Species Ailanthus altissima on Agro-Ecosystems on the Ionian Islands. Eng. Proc. 2021, 9, 19. https://doi.org/10.3390/ engproc2021009019

Academic Editors: Dimitrios Kateris and Maria Lampridi

Published: 25 November 2021

Publisher's Note: MDPI stays neutral with regard to jurisdictional claims in published maps and institutional affiliations.

Copyright: (c) 2021 by the authors. Licensee MDPI, Basel, Switzerland. This article is an open access article distributed under the terms and conditions of the Creative Commons Attribution (CC BY) license (https:// creativecommons.org/licenses/by/ $4.0 /)$.

\begin{abstract}
There is a significant number of agricultural systems with rich and special biodiversity, characterized as high-nature-value farming systems (HNV) in the Ionian Islands region. These agro-ecosystems cover a significant area in this region and are divided in olive groves and vineyards which, in some cases, cover a significant part of the protected areas (Natura 2000 and SPA). There are solid olive groves but also a large number of scattered trees or clusters, as well as vineyards, which are largely identified as high-quality wine producers. Finally, there are smaller but extremely important examples of HNV, such as the Englouvi plateau in Lefkada. In this study, we propose a method to survey the spread of Ailanthus altissima in olive groves and vineyards (HNV areas) with the scope of evaluating the considered agro-ecosystems, based on the importance of ecosystems and ecosystem services they provide, and preparing a management plan for HNV areas.
\end{abstract}

Keywords: remote sensing; geographic information systems; decision making; AHP

\section{Introduction}

Approximately half the area of Greece used for agricultural purposes has a high nature value (HNV) [1]. Total agricultural and forest land covers $51 \%$ of the total area, of which $18 \%$ is forests, $15 \%$ is forest land used for grazing, and $18 \%$ is cultivated land. HNV are the oldest and most biodiversity-rich farming and forestry systems [2]. They are also characterized as semi-natural habitats, and wild species have been interdependent with low-intensity management by local communities [1].

Alianthus altissima is an opportunistic plant that thrives in full sun and disturbed areas; it is a deciduous, very-fast-growing, invasive tree weed, versatile at different lighting intensities, adapting to almost all soil types (from the most fertile to barren, rocky); it does not thrive in soils that drain freely; it adjusts to a wide range of temperatures (such as high temperatures), and it adapts to saline soils [3]. There are direct dangers from its spread, such as: its effect on the soil fertility, fast decomposition rate of plant residues, reduction of photosynthesis, increase of microbium activity, and change in $\mathrm{pH}$ [3].

According to the literature [4], ecosystem services, i.e., the benefits that humans reap from nature, have been the subject of different classifications, according to generally accepted definitions in terms of their content. More specifically, they take into consideration many aspects of living organisms and biomes, such as biodiversity, production/supply services (production of food, water, biomass), climate regulation (rainfall, groundwater, and waste services), cultural/intangible services (aesthetic value of rural landscape), leisure 
services, spiritual uplift and inspiration, and support services (soil formation, soil retention, photosynthesis, concentration, and utilization of nutrients).

In this study, we propose a method to survey the spread of Ailanthus altissima in olive groves and vineyards (HNV areas) with the scope of evaluating the considered agro-ecosystems based on the importance of ecosystems and ecosystem services, and prepare a management plan for HNV areas. We used the geographic information system (GIS), remote sensing (RS), information technology (IT), and communication technology to capture the level of threat and develop effective response plans, through a fuzzy synthetic evaluation system [5].

\section{Study Area}

The area of interest is the HNV area of the four largest islands of the Ionian Islands (Table 1). The study area is located at the Ionian region and consisted of 372,000 acres of crops. Furthermore, the area is covered by vines and olive trees, 35,000 acres $(9.4 \%)$ and $337,000(90.6 \%)$, respectively (Figure 1). The Ionian landscape consists mainly of solid olive groves, scattered trees and vines that shape a complex geography, with points of retreat and/or abandonment, tourism and access to the coastline and connection with rural history. These historic crops offer many of the rural landscape characteristics of insular ecosystems, which combine rich habitats and local identity [6]. Despite their highly acclaimed importance, regarding biodiversity and ecosystem services, vineyards and olive groves are tormented by abandonment, deforestation/desertification and slow development with shrinking trends.

Table 1. Total cover of HNV areas.

\begin{tabular}{cc}
\hline HNV Areas & Total Cover \\
\hline Corfu & $46.2 \%$ \\
Zakynthos & $26.1 \%$ \\
Lefkada & $16.1 \%$ \\
Cephalonia & $11.6 \%$ \\
\hline
\end{tabular}
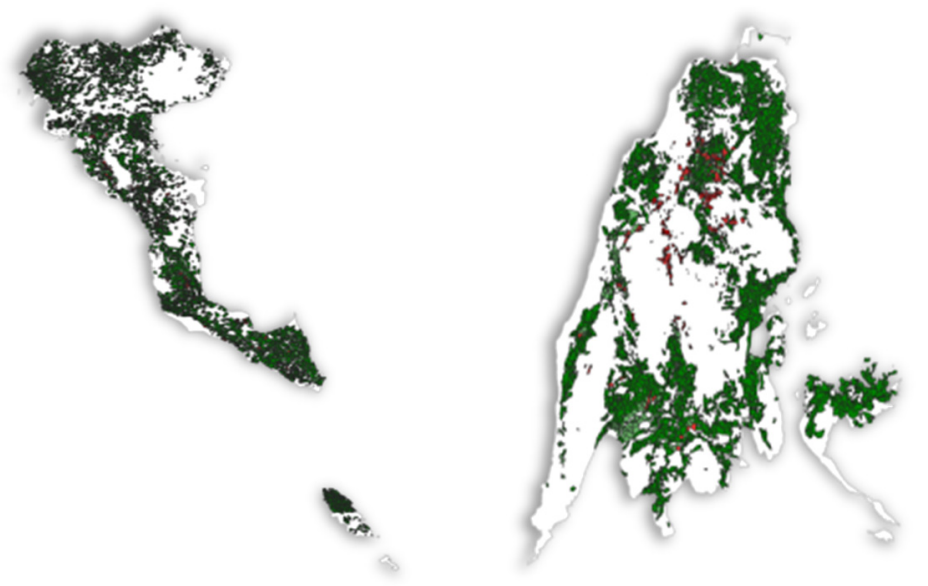

(a)

(b)

Figure 1. Affected HNV sites form Corfu (a) and Lefkada (b).

\section{Methodology}

Expansive alien species are a serious threat to these systems, producing the danger of spreading unwanted vegetation on agricultural land, while their risk is also identified and recognized in community legislation on biodiversity protection (Annex II of Article 6 of the CFP Regulation) [7]. A very dangerous area-expanding type of weed, Ailanthus altissima, 
which now threatens the natural environment, including crops (olive and viticulture) in the Ionian region, is the research subject that this work focuses on.

\subsection{Mapping}

More specifically, we created land cover/land use maps based on orthophotos of 0.5 resolution (SENTINEL-2) [8], which where overlayed by geospatial data (polygon type vectors) from Corine 2018 [9] and ILOT [10]. All of the study area was analyzed and produced mapping products, indicating the affected sites in the Ionian region (Figure 1). Furthermore, we created land cover/land use (LCLU) maps based on the aforementioned vector data, combined with field observations, in order to determine the affected sites in the Ionian Islands region [11].

\subsection{Policy Recommendations}

The initial findings of the study are crucial to identify the possible interactions between the parameters of alien species' spread, which lead to the construction of specific models and corresponding evaluation scenarios [12]. In the case of the Ionian region, the lack of data has created difficulties in the past during the process of the issue. We produced continuous data and comparable information on the subject, which is expected to enhance the on-site research outcomes and further support public evaluation of the studied agroecosystems.

\section{Results}

The proposed decision support system was built by applying AHP (Tables S2-S4) that is then supported by SWOT analysis processes (Figure S2). Through our research, we proposed a decision support system based on an applicable evaluation framework for assessing project alternatives by employing multi-criteria assessment. More specifically, we employed the analytical hierarchy process (AHP), through a model that is based on criteria including factors related to A. altissima, ecological impacts, and LCLU on the farming system [13].

\section{Conclusions}

This work is the first major study of invasive species in the Ionian region. It proposes a management plan for areas of high natural value against the invasion of A. Alissima. Furthermore, it introduces a novel method for managing HNV farming areas and a tool for the further alignment of National policies to EU policies, concerning sustainability, environmental protection, and green growth. It may work as a tool to highlight the designation of origin for olive and vine products in the region. The results will be publicly available through a web platform (Figure S3) at a future point of our project.

Supplementary Materials: The following are available online at https:/ /www.mdpi.com/article/10 .3390/engproc2021009019/s1 https://tinyurl.com/efita241: Figure S1: Coverage in acres for Olives (a) and Vines (b) within the area of interest. Figure S2: Results from the SWOT analysis. Figure S3: Proposed Web map. Table S1: The applied criteria for the AH process. Table S2: The results of the AH process. Table S3: AHP scoring rate.

Author Contributions: Conceptualization, Y.V. and P.B.; methodology, Y.V. and N.G.; software, A.S., P.M. and T.E.; validation, A.M. and K.K., data curation Y.V., A.S. and T.E.; supervision P.B. and P.M. All authors have read and agreed to the published version of the manuscript.

Funding: This research was funded by the European Union and Greece (Partnership Agreement for the Development Framework 2014-2020) under the Regional Operational Programme Ionian Islands 2014-2020 for the project "Assessment of the impact on biodiversity of High Nature Value Areas in the Region of Ionian Islands due to the invasion of the allocthonus plant species Ailanthus altissima (HNV-Threat)" (MIS code 5034911).

Institutional Review Board Statement: Not applicable. 


\section{Informed Consent Statement: Not applicable.}

Data Availability Statement: The data presented in this study are available on request from the corresponding author. The data are not publicly available due to the reason that this is an ongoing study.

Conflicts of Interest: The authors declare no conflict of interest.

\section{References}

1. Dimalexis, T.; Markopoulou, D.; Kourakli, P.; Manolopoulos, A.; Vitaliotou, M.; Chouvardas, D. Identification of High Nature Value Agricultural and Forestry Land; Hellenic Ornithological Society: Athens, Greece, 2008; p. 5.

2. Keenleyside, C.; Beaufoy, G.; Tucker, G.; Jones, G. High Nature Value Farming throughout EU-27 and Its Financial Support under the CAP; Report Prepared for DG Environment, Contract ENV B.1/ETU/2012/0035; Institute for European Environmental Policy: London, UK, 2014.

3. Miller, J.H. Ailanthus altissima (Mill.) Swingle Ailanthus. In Silvics of North America; US Department of Agriculture: Washington, DC, USA, 1990; pp. 101-104.

4. Fisher, B.; Turner, R.K. Ecosystem services: Classification for valuation. Biol. Conserv. 2008, 141, 1167-1169. [CrossRef]

5. Koschke, L.; Fürst, C.; Frank, S.; Makeschin, F. A multi-criteria approach for an integrated land-cover-based assessment of ecosystem services provision to support landscape planning. Ecol. Indic. 2012, 21, 54-66. [CrossRef]

6. Kefalas, G.; Kalogirou, S.; Poirazidis, K.; Lorilla, R.S. Landscape transition in Mediterranean islands: The case of Ionian islands, Greece 1985-2015. Landsc. Urban Plan. 2019, 191, 103641. [CrossRef]

7. Commission of the European Communities. Communication from the commission to the council, the European parliament, the European economic and social committee, and the committee of the regions: A mid-term assessment of implementing the EC biodiversity action plan. J. Int. Wildl. Law Policy 2009, 12, 108-120. [CrossRef]

8. Sentinel Online-ESA-Sentinel Online. Available online: https://earth.esa.int/web/sentinel/home (accessed on 13 April 2021).

9. CLC 2018-Copernicus Land Monitoring Service. Available online: https://land.copernicus.eu/pan-european/corine-landcover/clc2018 (accessed on 30 July 2021).

10. OPEKEPE.-Home Page. Available online: https:/ /www.opekepe.gr/en/ (accessed on 30 July 2021).

11. Lorilla, R.S.; Poirazidis, K.; Kalogirou, S.; Detsis, V.; Martinis, A. Assessment of the spatial dynamics and interactions among multiple ecosystem services to promote effective policy making across mediterranean island landscapes. Sustainability 2018, 10, 3285. [CrossRef]

12. Fernández Martínez, P.; de Castro-Pardo, M.; Barroso, V.M.; Azevedo, J.C. Assessing Sustainable Rural Development Based on Ecosystem Services Vulnerability. Land 2020, 9, 222. [CrossRef]

13. Benke, K.K.; Steel, J.L.; Weiss, J.E. Risk assessment models for invasive species: Uncertainty in rankings from multi-criteria analysis. Biol. Invasions 2011, 13, 239-253. [CrossRef] 